\title{
THE ROLE OF TECHNOLOGY AND CITIZENS' INVOLVEMENT IN SMART, INCLUSIVE AND SUSTAINABLE URBAN DEVELOPMENT
}

\author{
Ružica Bukša Tezzele (1), Raffaele De Amicis (2) \\ ${ }^{(1)}$ MSc, Fondazione GraphiTech, \\ (2) $\mathrm{PhD}$, Fondazione GraphiTech
}

Ružica Bukša Tezzele, MSc Fondazione GraphiTech Via alla Cascata 56/c - 38123 Trento (Italy) ruzica.buksa@gmail.com

Article info: Paper category: Review Received: 23.6.2015. Accepted: 13.11.2015.

JEL classification: $\mathrm{M}_{41}, \mathrm{O}_{1}, \mathrm{P}_{45}, \mathrm{~N}_{5}$ 


\begin{abstract}
Human participation and the use of technology are considered as key factors for smart and sustainable urban development. Over the past decade, governments, academic community and organized civil society have been turning their attention to solving urban problems with the new tools of advanced technology. Based on three years of $R \& D$, this paper aims to identify crucial factors for citizens' involvement in development and adoption of smart city services. It will bring out the results of citizens' involvement in the i-SCOPE project and explore why some European communities have succeeded in involving their citizens, and the others have not.
\end{abstract}

\title{
Keywords:
}

smart city, urban development, technology, citizen involvement 


\section{INTRODUCTION}

Cities have always been considered as places of socio-economic development and urban culture. Nowadays, more than half of the world's population lives in cities. The world continues to urbanize and by United Nations projections, it is expected that more than $66 \%$ of the world's population will live in urban areas by 2050 (United Nations, 2014: 2).

At the present, there are more than 3 billion Internet users in the world, twothirds of them coming from the developing countries, and the number of mobilebroadband subscribers has already reached 2.3 billion globally (Internet World Stats 2015. International Telecommunication Union 2015). Thanks to mobile devices, citizens have become the real and best sensors for collecting real useful data.

The rapid growth of world's population and continuous advancements in technology indicate to a great potential of ICT to ensure smart, inclusive and sustainable urban development.

In 1990s, the concept of smart cities was introduced to signify how urban development was turning towards technology and innovation (Schaffers et al, 2011: 433). Special attention is given to the use of information technology and participatory government to meet the challenges of cities within a global knowledge economy. Cities have to face many challenges, such as growing population, poverty, environment pollution, lack of infrastructure, traffic congestion, increased energy consumption to name but a few. Therefore, there is a great need for sustainable and inclusive development, different understanding of prosperity that goes beyond GDP, and holistic multidisciplinary approach that connects natural and social sciences, as well as science and policy making.

Smart cities are all about collaboration, sharing and transparency. They bring together technology, society and government to enable smart governance, smart economy, smart mobility, smart environment, smart people and smart living (Manville et al, 2014: 28). The crucial roles play ICT infrastructure, open data and technological devices that enable the exchange of millions of messages on a daily basis. But just the ICT solutions and technology advancements cannot make the expected impact on smart and sustainable urban development. The key role plays human capital and the adoption of new, complex technologies. The ageing population, lack of information and social responsibility of local administrations and companies to pave the way towards the better future can lead to a poor citizens' adoption of new technologies and therefore their poor participation in shaping local policies and building smart, inclusive and sustainable urban communities.

This paper consists of six main sections. After the introduction, the second section gives the overview of related work. The third section describes the research framework. It is followed by the explanation of the methodology that has been used in the research and data collection. The fifth section presents the results achieved 
during the three years of data collection and identifies crucial factors for citizens' involvement in development and adoption of smart city services. In the last section are presented concluding remarks.

\section{RELATED WORK}

In the last decade, a number of studies have shown that the use of information technology can enhance the management and functioning of cities. E-government has become widely applied with proponents claiming that it guarantees transparency and better communication between local and national administrations and citizens (Cegarra-Navarro et al, 2011: 469). It also represents one of the first steps in transforming a city into a smart city. The transformation to smarter cities usually requires innovation in planning, management and operations (Nephade et al, 2011: 32).

According to Nam and Pardo, making a city smart is a new approach to urban development. The smart city approach is emerging as a way to solve tangled and wicked problems inherited in the rapid urbanization. They consider smart city a contextualized interplay among technological innovation, managerial and organizational innovation, and policy innovation (Nam and Pardo, 2011: 185).

In Harrison et al.'s study, smart cities are denoted as instrumented, interconnected and intelligent. Instrumentation enables to capture and integrate near realtime data through the use of sensors, personal devices, smartphones, cameras etc. Interconnection means the integration of those data into an enterprise computing platform and communication of such information among various city services. Intelligent refers to the inclusion of complex analytics, modeling, optimization and visualization in the operational business processes to make better operational decisions (Harrison et al, 2010: 1). This approach enables the adaptation of city services to the citizens' needs and permits the optimal use of the infrastructure and resources, e.g. in assessing and optimizing the energy consumption.

Washburn et al. define smart city as a collection of smart computing technologies applied to critical infrastructure components and services, such as city administration and utilities. Smart computing refers to a new generation of integrated hardware, software and network technologies that provide IT systems with real-time awareness of the real world and advanced analytics to improve decision making and optimize business processes (Washburn et al, 2010: 2).

The integration of ICT with development projects can change the urban landscape of a city and offer a number of potential opportunities, they can enhance the management and functioning of a city (Chourabi et al, 2012: 2291).

It is also important to stress the role of human capital and education in urban development. Smart cities have to have smart people that use the technology and actively participate in shaping urban environment. The smart people concept comprises various factors like affinity to life long learning, social and ethnic plurality, 
flexibility, creativity, open-mindedness, and participation in public life (Nam and Pardo, 2011: 287).

All smart city studies have three categories in common: technology, people and institution. Given the connection between them, a city is smart when investments in human capital and IT infrastructure fuel sustainable economic growth and a high quality of life, through participatory governance (Caragliu et al, 2011: 70).

\section{RESEARCH FRAMEWORK}

i-SCOPE (Interoperable Smart City services through an Open Platform for urban Ecosystems) project is a EU-funded project, started in January 2012 with a duration of 4.4 months. It aims to deploy added-value services (in the field of energy saving, noise pollution and mobility) on the top of 3D representation of the territory, exploiting the geometrical, topological and semantic information that describe urban environment. Smart services address three scenarios: improved inclusion and personal mobility of elderly and diversely-abled citizens, optimization of energy consumption through a service for accurate assessment of solar energy potential and energy loss at building level, and environmental monitoring through a real-time environmental noise mapping service. The smart routing service, accessible from the online platform and 3D mobile client, takes into account detailed urban layout, features and barriers in order to provide orientation and navigation information to pedestrians and diversely-able users on how to reach one destination from another, avoiding diverse architectural barriers on their way. The solar energy service improves energy efficiency and enables users to perform a detailed simulation of each roof's solar energy potential in pilot sites and create energy dispersion maps. The noise mapping service enables citizens to measure noise levels using their smartphones as "noise sensors" and create real-time noise maps that can be used to better understand urban noise pollution and help city administrations in decision and policy making.

The target users of the i-SCOPE project are elderly and diversely-abled citizens needing customized barrier-free routing instructions, city administrations that need to define policies in terms of heat dispersion and solar potential at urban level, professionals who need to have high precision solar potential assessment, city administrations that need to assess noise and create noise maps according to EU Environmental Noise Directive 2002/49/EG, and citizens, who can access real-time data.

The project consortium is composed of 20 European partners, among which research centers, universities, industries and local public administrations, coming from 10 European countries. The consortium has been structured in a way that each city administration works in close relationship with one technology provider. This ensures a strong bond between the final user and those in charge of the deployment of services, as well as better involvement of users in the project activities. Geographi- 
cal proximity ensures also better and faster communication that is especially important during the testing phase and user's adoption of the final services.

After three years of project activities, the consortium has successfully developed mobile applications and i-SCOPE platform that enables access to three smart services for nine pilot locations. The services benefit from GityGML urban information model, official OGC Standard. The consortium has also involved public administration in the project, and created exploitation and business plan. A number of citizens living within the pilot partners' municipalities have been involved, but not as much as it was expected. On the other side, a lot of interest in the project outcomes has been gained from communities outside Europe, such as Chicago and Hong Kong.

The i-SCOPE project developed smart city services that should be easily adopted by citizens and significantly improve the quality of life in the pilot locations.

$\mathrm{H}_{1}$ : The i-SCOPE technology is complex but user-friendly compared to other existing technologies for 3D visualization of a territory currently available on the market.

The i-SCOPE mobile applications and platform are user-friendly even though behind them stands a development of complex technologies that enable contemporary 3D visualization of a territory. These technologies are developed with the intention to be widely used by citizens, and therefore require simpler codes compared to for example QGIS (Geographic Information System tool in open-source community), that uses complex codes and is designed for professionals. This user-friendliness should help to involve citizens in adoption and use of smart city services developed in the i-SCOPE project.

$\mathrm{H}_{2}$ : City administrations are interested in deployment of i-SCOPE smart city services and able to bring them closer to the citizens to enhance their involvement in shaping smart and sustainable urban centers.

Smart city services developed in the i-SCOPE project can bring significant help to city administrations in defining policies in terms of heat dispersion and solar potential, as well as in assessing noise levels to create noise maps according to EU Directive 2002/49/EC. Therefore, it is in their interest to convey citizens towards the use of smart city services, especially to collect real useful data that will help them to create better environment and improve the quality of life inside the boundaries of the area they manage.

\section{METHODOLOGY}

The project partners have defined the number of users that they want to involve in the project in nine pilot locations: the Municipality of Baia Mare, the Municipality of Indjija, the Municipality of Newcastle, the Municipality of Trento, the Municipality of Vienna, the Municipality of Zagreb, the Lazio region, the Zadar County and the Malta Harbour area. Each location differs in geographical position, size, number of inhabitants, culture, economic development, policies, infrastructure, local administration involvement and interest in certain smart services that will be developed and tested within the project. 
Table 1 . shows quantitative objectives related to the users' involvement in pilot partners' locations defined at the beginning of the project.

Table 1.: Involvement of users

\begin{tabular}{|l|r|r|r|r|}
\hline Location & $\begin{array}{c}\text { Citizens } \\
\text { affected by } \\
\text { the i-SCOPE } \\
\text { technology }\end{array}$ & $\begin{array}{c}\text { Experts within } \\
\text { city department } \\
\text { offices }\end{array}$ & $\begin{array}{c}\text { Professionals } \\
\text { (external of city } \\
\text { department } \\
\text { offices) }\end{array}$ & Academia \\
\hline Baia Mare & 200 & 20 & 20 & 5 \\
Indjija & 50 & 10 & 30 & 20 \\
Lazio & 500 & 20 & 0 & 0 \\
Malta & 200 & 20 & 35 & 0 \\
Newcastle & 120,000 & 20 & 50 & 50 \\
Trento & 200 & 5 & 0 & 30 \\
Vienna & 50 & 10 & 50 & 0 \\
Zadar & 200 & 10 & - & 0 \\
Zagreb & 1,000 & 135 & 185 & 0 \\
Total & $122,4,00$ & & & 0 \\
\hline
\end{tabular}

Source: Research proposal.

The citizens' involvement process is composed of three key phases. In the first phase, the citizens and other relevant actors were provided with the general information about the project. In the second phase, they were provided with the general presentation of the project evolution (initiated and finalized actions, first results). Dialogue with citizens and collecting feedback was enhanced, and citizens were involved in testing and improving the prototypes and products. We are currently in the final phase, where citizens and other relevant actors are provided with the general presentation of the final results and the implementation of the prototypes.

In order to raise awareness and involve citizens, the partners have agreed to undertake a lot of dissemination activities: to give a number of presentations and lectures, organize meetings, workshops, surveys, advertisement campaigns, participate to the conferences, issue press releases, newspaper and magazine articles, online articles, publications (books, leaflets, brochures) and keep the project website and social media channels continuously updated. For each target group have been defined engagement activities and key messages to convey, taking into account the needs addressed and benefits provided through the project (Table 2.). 
Table 2.: Target users and engagement activities to address their needs

\begin{tabular}{|c|c|c|}
\hline Target users & Engagement activities & $\begin{array}{l}\text { Needs addressed and } \\
\text { benefits provided by services }\end{array}$ \\
\hline Citizens & $\begin{array}{l}\text { Presentations, lectures, } \\
\text { meetings, workshops, surveys, } \\
\text { advertisement campaigns, } \\
\text { press releases, newspaper } \\
\text { and magazine articles, online } \\
\text { articles, publications, website } \\
\text { and social media }\end{array}$ & $\begin{array}{l}\text { Routing service (orientation } \\
\text { and navigation information } \\
\text { taking into account avoiding } \\
\text { architectural barriers on the } \\
\text { way), optimization of energy } \\
\text { consumption (assessment of } \\
\text { roof's solar energy potential, } \\
\text { cost-benefit analysis related } \\
\text { to installation of solar and } \\
\text { photovoltaic panels), noise } \\
\text { mapping service (measurement } \\
\text { of noise level in the area of } \\
\text { interest or when filling a } \\
\text { complaint for excessive noise } \\
\text { exposure) }\end{array}$ \\
\hline $\begin{array}{l}\text { Experts within city department } \\
\text { offices }\end{array}$ & $\begin{array}{l}\text { Presentations, lectures, } \\
\text { meetings, workshops, press } \\
\text { releases, newspaper and } \\
\text { magazine articles, online } \\
\text { articles, publications }\end{array}$ & $\begin{array}{l}\text { Routing service (definition } \\
\text { of mobility routes inside the } \\
\text { boundaries of the area they } \\
\text { manage), assessment of solar } \\
\text { energy potential (definition of } \\
\text { energy-saving policies and to } \\
\text { promote deployment of solar } \\
\text { and photovoltaic panels within } \\
\text { specific areas of the city), } \\
\text { noise mapping service (better } \\
\text { understanding of urban noise } \\
\text { pollution and creation of noise } \\
\text { maps according to EU Directive } \\
\text { 2002/49/EC) }\end{array}$ \\
\hline $\begin{array}{l}\text { Professionals (external of city } \\
\text { department offices) }\end{array}$ & $\begin{array}{l}\text { Presentations, lectures, } \\
\text { meetings, workshops, } \\
\text { newspaper and magazine } \\
\text { articles, online articles, } \\
\text { publications, website and social } \\
\text { media }\end{array}$ & $\begin{array}{l}\text { Assessment of solar energy } \\
\text { potential (improvement of } \\
\text { energy performance and } \\
\text { cost-benefit analysis related } \\
\text { to installation of solar and } \\
\text { photovoltaic panels) }\end{array}$ \\
\hline Academia & $\begin{array}{l}\text { Presentations, lectures, } \\
\text { meetings, workshops, } \\
\text { conferences, newspaper and } \\
\text { magazine articles, publications, } \\
\text { website and social media }\end{array}$ & $\begin{array}{l}\text { Routing service, optimization } \\
\text { of energy consumption and } \\
\text { noise mapping service (experts } \\
\text { and academics in the mobility, } \\
\text { energy efficiency and noise } \\
\text { mapping domains can further } \\
\text { capitalize on the findings } \\
\text { from the project and provide } \\
\text { valuable feedback on developed } \\
\text { solutions). }\end{array}$ \\
\hline
\end{tabular}

Source: Authors.

The set of indicators, together with the expected yearly progress, has been defined to monitor the success of dissemination activities along the project duration (Table 3.). 
Table 3.: Definition of inDICATORS and expected results after each year of the project activities

\begin{tabular}{|l|r|r|r|}
\hline \multicolumn{1}{|c|}{ Indicator } & \multicolumn{1}{|c|}{$\begin{array}{c}\text { Expected results } \\
\text { after first year }\end{array}$} & $\begin{array}{c}\text { Expected results } \\
\text { after second year }\end{array}$ & $\begin{array}{c}\text { Expected results } \\
\text { after third year }\end{array}$ \\
\hline $\begin{array}{l}\text { Number of training } \\
\text { workshops organized } \\
\text { by i-SCOPE partners }\end{array}$ & 2 & 7 & 12 \\
$\begin{array}{l}\text { Number of articles, } \\
\text { papers, publications }\end{array}$ & 5 & 10 & 15 \\
$\begin{array}{l}\text { Number of } \\
\text { conferences and } \\
\text { events with the }\end{array}$ & 2 & 5 & 6 \\
$\begin{array}{l}\text { i-SCOPE evidence } \\
\text { Number of newsletter } \\
\text { subscribers }\end{array}$ & 30 & 60 & 120 \\
$\begin{array}{l}\text { Number of public } \\
\text { presentations } \\
\text { performed }\end{array}$ & 10 & 20 & 40 \\
\hline
\end{tabular}

Source: Research proposal.

Every six months partners have filled in a questionnaire and made a report on dissemination activities and citizens' involvement. Due to notable discrepancies between planned and achieved results, 18 months after the project has started, the methodology has been changed. It was decided that partners have to send bi-monthly and six-monthly reports to the project management team. It was also decided that more attention should be given to raising citizens' awareness. Thus, pilot partners have agreed to organize at least two events per semester and provide press releases and pictures of events in order to be published on local websites and on the i-SCOPE portal.

\section{RESULTS AND DISCUSSION}

Citizens' involvement in the i-SCOPE project is an essential strategic element that allows demonstration of the use of the smart services that have been developed during the project. The citizens are one of the most important final users of developed services.

During the three years, the partners have undertaken a number of activities in order to involve citizens, public administration, professionals and academia in development and testing of smart services that could bring meaningful and sustainable change in pilot partners' locations and increase the quality of life. More than a hundred press releases have been issued and a lot of other dissemination activities have been done in this period.

Table 4. shows the results of dissemination activities performed by partners in three years. 
Table 4.: The results of dissemination activities after three years

\begin{tabular}{|l|r|r|r|}
\hline \multicolumn{1}{|c|}{ Indicator } & $\begin{array}{c}\text { Results after first } \\
\text { year }\end{array}$ & $\begin{array}{c}\text { Results after second } \\
\text { year }\end{array}$ & $\begin{array}{c}\text { Results after third } \\
\text { year }\end{array}$ \\
\hline $\begin{array}{l}\text { Number of training } \\
\text { workshops organized } \\
\text { by i-SCOPE partners }\end{array}$ & $2(2)$ & $12(7)$ & $18(12)$ \\
$\begin{array}{l}\text { Number of articles, } \\
\text { papers, publications }\end{array}$ & $5(5)$ & $28(10)$ & $42(15)$ \\
$\begin{array}{l}\text { Number of } \\
\text { conferences and } \\
\text { events with the } \\
\text { i-SCOPE evidence } \\
\text { Number of newsletter } \\
\text { subscribers } \\
\text { Number of public } \\
\text { presentations } \\
\text { performed }\end{array}$ & $2(2)$ & $27(5)$ & $55(6)$ \\
\hline
\end{tabular}

Note: the expected results defined at the beginning of the project are shown in the parentheses. The * sign marks the negative deviations, i.e. the expected results have not been achieved.

Source: Research results.

The results in Table 4. show that the partners have performed even much more dissemination activities than it was planned at the beginning of the project. Despite a great number of publications, conferences and public presentations, the partners have not succeeded to achieve the expected number of newsletter subscribers that was important for spreading the news about the project and engagement of final users. The reason of this failure lays in the lack of newsletter promotion and complicated procedure for subscribing, i.e. there was no appropriate subscribing form on the project website and no invitation for subscription in newsletters.

Table 5. shows the results of users' involvement in the project for each pilot partner's location after three years of project activities.

Table 5.: The results of users' involvement in the project

\begin{tabular}{|l|r|r|r|r|}
\hline Location & $\begin{array}{r}\text { Citizens } \\
\text { affected by } \\
\text { the i-SCOPE } \\
\text { technology }\end{array}$ & $\begin{array}{c}\text { Experts within } \\
\text { city department } \\
\text { offices }\end{array}$ & $\begin{array}{c}\text { Professionals } \\
\text { (external of city } \\
\text { department } \\
\text { offices) }\end{array}$ & Academia \\
\hline Baia Mare & $200(200)$ & $20(20)$ & $20(20)$ & $5(5)$ \\
Indjija & $90(50)$ & $48(10)$ & $5(30)^{*}$ & $20(20)$ \\
Lazio & $500(500)$ & $2(20)^{*}$ & $50(0)$ & $0(0)$ \\
Malta & $0(200)^{*}$ & $28(20)$ & $29(0)$ & $49(0)$ \\
Newcastle & $\circ(120,000)^{*}$ & $6(20)^{*}$ & $3(35)^{*}$ & $1(50)^{*}$ \\
Trento & $100(200)^{*}$ & $100(20)$ & $30(50)^{*}$ & $10(30)^{*}$ \\
Vienna & $480(50)$ & $20(5)$ & $0(0)$ & $0(0)$ \\
Zadar & $187(200)^{*}$ & $8(10)^{*}$ & $4(0)$ & $0(0)$
\end{tabular}




\begin{tabular}{|l|c|r|r|r|}
\hline Location & $\begin{array}{c}\text { Citizens } \\
\text { affected by } \\
\text { the i-SCOPE } \\
\text { technology }\end{array}$ & $\begin{array}{c}\text { Experts within } \\
\text { city department } \\
\text { offices }\end{array}$ & $\begin{array}{c}\text { Professionals } \\
\text { (external of city } \\
\text { department } \\
\text { offices) }\end{array}$ & Academia \\
\hline Zagreb & $\begin{array}{c}150(1,000)^{*} \\
1,707(122,400)^{*}\end{array}$ & $40(10)$ & $40(50)^{*}$ & $20(0)$ \\
Total & $272(135)$ & $181(185)^{*}$ & $105(105)$ \\
\hline
\end{tabular}

Note: the expected results defined at the beginning of the project are shown in the parentheses. The * sign marks the negative deviations, i.e. the expected results have not been achieved.

Source: Research results.

The results in Table 5. show that some partners did not succeed to involve in the project as much users as it was defined at the beginning. The pilot partners in Malta, Newcastle, Trento, Zadar and Zagreb did not involve in the project as much citizens as it was planned. The pilot partners in Lazio, Newcastle and Zadar did not make it to involve enough experts within city department offices, while the pilot partners in Indjija, Newcastle, Trento and Zagreb did not involve in the project a planned number of professionals external of city department offices. The pilot partners in Newcastle and Trento also did not succeed to involve in the project as much members of academia as it was expected.

On a basis of collected data, we wanted to find out why some communities have failed in citizens' involvement. We have gone beyond the numbers and tried to find out the responses. We analyzed all collected reports and relationships between partner in charge on each pilot location and target users. The response was laying in city administration.

The sustainability of the project is connected to the capability of local administrations to convey citizens' interest towards the online platform and smart services, to involve them firstly as users, but also as co-designers of smart solutions. The research results have shown that the majority of local administrations have failed in this task, as they were more concerned about the implementation of the project, more precisely data collection, than exploiting the potentiality of a real e-inclusion of their citizens in enjoying the benefits of ICT. They were also concerned about citizens' acceptance of smart city technologies.

During the research period some trends have been identified, especially the different pace and level of engagement of territorial partners. There are clear dissimilarities between the cities, differences generated by planning traditions, the variance in the number of people and the level of involvement of the local authorities in the process. Low level of engagement of partner in Malta has led to the absence of citizens' involvement in the project in that pilot location. Such result is a consequence of their concern about the implementation of the project and final outcomes (will the services work properly and be useful or not). Some of the pilot partners (e.g. Zagreb, Zadar) have been more affected by the recent economic crisis and the process of citizens' involvement has become more difficult. 
One of the reasons for not involving enough users in the project also lays down in the fact that the developed online platform and smart services require the use of newer technological devices, computers and smartphones of certain power and speed, as well as developed network infrastructure that were not available to all users. City administrations (such as Newcastle) did not want to promote the technology and services that citizens could not or could hardly use. Instead of looking on the long-term benefits of exploiting such a technology and services, they were more concerned on the short-term results and problems they faced.

Management and organization also play crucial role in citizens' involvement in the project. Complex organizations and local authorities require respecting long procedures, especially for authorization of certain activities such as organization of events with target users in order to bring the technology closer to them and enable testing on site, as well as direct dialogue and collecting feedback. Such procedures are not stimulating at all, and often lead to renouncing of any activity. This situation has been particularly noticed in Trento pilot location and has led to a poor citizens' involvement in the project and adoption of developed smart city services.

The results in Table 5 . show also that some partners have succeeded to involve citizens in the project, such as pilot partners in Baia Mare, Indjija, Lazio and Vienna. All of them have successfully overcome the problems related to technology and infrastructure requirements as well as management and organization, and have actively participated in the project. They have done a lot of dissemination activities and have been very active in using the social media channels to engage with the citizens and enhance the communication. The pilot partner in Baia Mare has also done a number of meetings with high school students and various stakeholders in order to promote the project and invite them to test developed services. The pilot partner in Indjija has organized a number of workshops, presentations to university students, noise survey campaign in Belgrade, meetings with local government, public and private companies, and all these activities have brought the i-SCOPE services closer to the citizens, they had the opportunity to test them and provide feedback for their improvement. The pilot partner in Lazio has also organized a number of meetings with public authorities and associations, as well as presentations of the project platform to the citizens. The pilot partner in Vienna has organized a series of discussions to promote citizens' involvement in decision-making in the City, inviting also companies and organizations to join. It has also published a number of articles in print media and on online city portal to invite citizens to test the i-SCOPE services.

The results of our research show that the initially set hypothesis stating that the i-SCOPE technology is complex but user-friendly compared to other existing technologies for 3D visualization of a territory currently available on the market is accepted. The user-friendliness has been recognized in all pilot locations except Newcastle. Young population, such as high school and university students have been the most interested in the i-SCOPE technology as well as smart city services developed 
in the project. They consider them useful for shaping the future of their cities, while most of adults have been more interested in the economic benefits of these services.

The second set hypothesis stating that city administrations are interested in deployment of i-SCOPE smart city services and able to bring them closer to citizens to enhance their involvement in shaping smart and sustainable urban centers can be just partially accepted. Our research has shown that not all city administrations have recognized the potential of the i-SCOPE smart city services and did not want to engage in the project until they see tangible results and that the developed technology work. Such attitude is not good for introducing new technologies and brining changes in the area they manage, and could lead to constant lagging in urban development.

The results of our research indicate that crucial factors for citizens' involvement in development and adoption of smart city services are user-friendly technology, good infrastructure that will enable such technology to work properly, management and organization, engagement of local administration, as well as their capability to understand the complex technology and bring it closer to the citizens. Citizens' involvement in development of smart city services can provide valuable feedback and improve the services to be more useful to the community. On the other side, local administrations have to understand the benefits of such technology for improving the process of collecting useful and real-time data, enhancing the process of decision making, and increasing citizens' participation in shaping smart and sustainable cities.

\section{CONCLUSION}

The concept of smart city implies the use of complex technologies that can improve the quality of life. Our research has shown that there are some crucial factors that play the key role in citizens' adoption of new smart solutions, such as userfriendly technology, infrastructure, management and organization, and the most important, interest, capability and social responsibility of local administrations. People need to be able to use the technology in order to benefit from it. Therefore, there is a big challenge for local administrations to deploy complex technologies and bring them closer to the citizens.

Citizens are no longer just passive observers, and thanks to the new information and communication technologies they can play an active role in shaping smart and sustainable urban centers. But local administrations need to be the main leaders, they are the ones that can improve the city management by means of smart technology.

The citizens' involvement in development and adoption of new technologies is a complex, non linear process that requires time and a lot of effort, especially from partners and city administrations. Since the project is currently in its final phase, it can be expected that some more citizens will get involved in testing the online plat- 
form and final services. This will primarily depend on interest and capability of local administrations to bring the technology closer to the citizens. The research results have shown that those communities that have competent, proactive administrations, interested in improving city management and quality of life, have obtained the best results of citizens' involvement in the project. Such communities have seen the potential of new technology to create a sustained change that will last beyond the project.

\section{ACKNOWLEDGEMENT}

This research has been supported by the European Commission within the project i-SCOPE. The authors are solely responsible for the content of the paper. It does not represent the opinion of the European Commission. The European Commission is not responsible for any use that might be made of information contained herein. 


\section{REFERENCES}

Caragliu, Andrea, et al, "Smart cities in Europe", Journal of urban technology 18, no. 2, (2011): 65-82. Accessed November 9, 2015. doi:10.1080/10630732.2011.601117

Cegarra-Navarro, Juan-Gabriel, et al, "E-government and citizen's engagement with local affairs through e-websites: The case of Spanish municipalities", International Journal of Information Management 32, no. 5, 2012:469-478. Accessed November 9, (2015), doi:10.1016/j.ijinfomgt.2012.02.008

Chourabi, Hafedh, et al, "Understanding smart cities: An integrative framework", In Proceedings of the $45^{\text {th }}$ Hawaii International Conference on System Sciences. IEEE,: (2012): 2289-2297. Accessed November 9, 2015. doi:10.1109/HICSS.2012.615

European Parliament, Council of the European Union, "Directive 2002/49/EC of the European Parliament and of the Council of 25 June 2002 relatingto the assessmentand management of environmentalnoise". (2002), Accessed March 26, 2015. http://eur-lex.europa.eu/legal-content/EN/TXT/?uri=celex:32002Loo49

Harrison, Colin, et al, "Foundations for Smarter Cities", IBM Journal of Research and Development ${ }_{15}$, (2010):1-16. Accessed November 9, 2015. doi:10.1147/JRD.2010.204.8257

International Telecommunication Union, "The World in 2015: ICT Facts and Figures", (2015), Accessed November 9, 2015, http://www.itu.int/en/ITU-D/Statistics/Pages/facts/default.aspx

Internet World Stats., "Internet Usage Statistics", (2015), Accessed November 9, 2015. http://www. internetworldstats.com/stats.htm

Nam, Taewoo, and Theresa A. Pardo, "Conceptualizing smart city with dimensions of technology, people, and institutions", In Proceedings of the 12th Annual International Digital Government Research Conference: Digital Government Innovation in Challenging Times. ACM, (2011): 282-291. Accessed November 9, 2015. doi:10.1145/2037556.2037602

Nam, Taewoo, and Theresa A. Pardo, "Smart city as urban innovation: Focusing on management, policy,

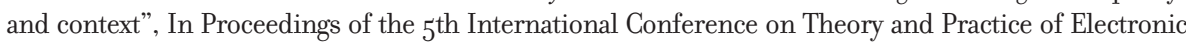
Governance, ACM, (2011): 185-194. Accessed November 9, 2015. doi:10.1145/2072069.2072100

Naphade, Milind, et al, "Smarter Cities and Their Innovation Challenges", Computer 44, no. 6, (2011):3239. Accessed November 9, 2015. doi:10.1109/MC.2011.187

Manville, Catriona, et al, "Mapping Smart Cities in the EU", Bruxelles: European Parliament, Policy Department A: Economic and Scientific Policy, (2014), Accessed March 26, 2015. doi:10.2861/34,08

Schaffers, Hans, et al, "Smart Cities and the Future Internet: Towards Cooperation Frameworks for Open Innovation", In The Future Internet, edited by John Domingue et al., (2011): 431-446. Berlin Heidelberg: Springer, LNCS 6656. Accessed March 26, 2015. doi:10.1007/978-3-642-20898-o_31

United Nations, "World Urbanization Prospects: The 2014 Revision", (2014), Accessed March 21, 2015. http://esa.un.org/unpd/wup/Highlights/

Washburn, Doug, et al, "Helping CIOs understand", smart city" initiatives. Cambridge: Forrester Research., (2010), Accessed November 9, 2015. http://www.uwforum.org/upload/board/forrester_help_ cios_smart_city.pdf 
